\title{
Does grazing of cover crops impact biologically active soil carbon and nitrogen fractions under inversion or no tillage management?
}

\author{
A.J. Franzluebbers and J.A. Stuedemann
}

\begin{abstract}
Cover crops are a key component of conservation cropping systems. They can also be a key component of integrated crop-livestock systems by offering high-quality forage during short periods between cash crops. The impact of cattle grazing on biologically active soil carbon $(\mathrm{C})$ and nitrogen $(\mathrm{N})$ fractions has not received much attention. We investigated the impacts of tillage (conventional disk and no tillage) and cover crop management (ungrazed and grazed) on biologically active soil $\mathrm{C}$ and $\mathrm{N}$ fractions from biennial sampling during seven years of continuous management. Soil microbial biomass $\mathrm{C}$ was unaffected by cover crop management under conventional tillage, but was enhanced with grazing compared with no grazing under no tillage at a depth of 0 to $6 \mathrm{~cm}$ (0 to $2.4 \mathrm{in})$, as well as at 0 to $30 \mathrm{~cm}$ (0 to $12 \mathrm{in}$ ). The same effect occurred for the flush of carbon dioxide $\left(\mathrm{CO}_{2}\right)$ following rewetting of dried soil during 3 days of incubation at a depth of 0 to $6 \mathrm{~cm}$ only, while it occurred for cumulative $\mathrm{C}$ mineralization during 24 days of incubation at a depth of 0 to $30 \mathrm{~cm}$ only. Grazing effects on net $\mathrm{N}$ mineralization during 24 days of incubation and residual soil inorganic $\mathrm{N}$ were nonexistent. All biologically active fractions of soil $\mathrm{C}$ and $\mathrm{N}$ were highly stratified with depth under no tillage and less so under conventional tillage. Cumulative stocks of soil $\mathrm{C}$ and $\mathrm{N}$ fractions to a depth of 0 to $30 \mathrm{~cm}$ were generally not significantly different between cover crop management systems, nor between tillage systems, except for (1) lower soil microbial biomass $\mathrm{C}$ with than without grazing under conventional tillage, (2) greater soil microbial biomass $\mathrm{C}$ with than without grazing under no tillage, and (3) lower cumulative $\mathrm{C}$ mineralization during 24 days under no tillage than under conventional tillage. Grazing of cover crops can be recommended as a strategy to promote greater adoption of cover cropping throughout the southeastern United States.
\end{abstract}

Key words: cover crop management-flush of carbon dioxide- net nitrogen mineralization-no tillage-soil microbial biomass carbon

\begin{abstract}
Cover crops are a key component of conservation agricultural systems (Delgado et al. 2011). They protect soil from water and wind erosion during vulnerable fallow periods between successive cash cropping periods. Cover crops also provide considerable carbon (C) input following termination of growth, which contributes to maintenance and increases in soil organic C (Franzluebbers 2010). Belowground C input may be equally important as aboveground $\mathrm{C}$ input to soil, since living and dead roots provide readily available sources of food for soil
\end{abstract}

microbial activity to transform nutrients and alter soil structure (Hinsinger et al. 2009).

Various cover crops have been grown successfully during the relatively mild winter conditions in the southeastern United States, most notably rye (Secale cereale L.), wheat (Triticum aestivum L.), and crimson clover (Trifolium incarnatum L.). During three years on a sandy loam soil in Georgia, aboveground biomass accumulation was $4.1 \pm 1.9$ $\mathrm{Mg} \mathrm{ha}{ }^{-1}\left(3,660 \pm 1,700 \mathrm{lb} \mathrm{ac}^{-1}\right)$ for rye, 4.2 $\pm 1.5 \mathrm{Mg} \mathrm{ha}^{-1}\left(3,750 \pm 1,340 \mathrm{lb} \mathrm{ac}^{-1}\right)$ for hairy vetch (Vicia villosa Roth), and $6.6 \pm$ 1.4 $\mathrm{Mg} \mathrm{ha}^{-1}\left(5,890 \pm 1,250 \mathrm{lb} \mathrm{ac}^{-1}\right)$ for rye combined with vetch (Sainju et al. 2005). During four years on a fine sand in Georgia, biomass accumulation was $1.8 \pm 0.8 \mathrm{Mg}$ $\mathrm{ha}^{-1}\left(1,610 \pm 710 \mathrm{lb} \mathrm{ac}^{-1}\right)$ for balansa clover (Trifolium michelianum Savi) and crimson clover, $2.9 \pm 1.1 \mathrm{Mg} \mathrm{ha}^{-1}\left(2,590 \pm 980 \mathrm{lb} \mathrm{ac}^{-1}\right)$ for Austrian winter pea (Pisum sativum L. ssp. arvense), black oat (Avena strigosa Schreb.), hairy vetch, and oil-seed radish (Raphanus sativus L.), and $4.6 \pm 1.7 \mathrm{Mg} \mathrm{ha}^{-1}$ (4,110 $\pm 1,520 \mathrm{lb} \mathrm{ac}^{-1}$ ) for rye (Schomberg et al. 2006). These cover crops typically have high forage quality at early to mid-growth stages, and therefore, could be potentially grazed to replace or at least offset some costs of expensive winter feeding of livestock (Schomberg et al. 2014). Conservation program managers and producers have been reluctant to routinely use this approach, however, due to the potential for poaching of soil leading to livestock-induced soil compaction and potential erosion. In a cotton (Gossypium) cropping system in northern Alabama, grazing of winter wheat cover crop by cattle caused compaction within the surface $15 \mathrm{~cm}$ (6 in) of soil, resulting in reduced yield in two of three years following grazing compared with a cover crop not grazed (Mullins and Burmester 1997). In northern Georgia, soil bulk density was mostly unaffected by whether rye cover crop was grazed or not (except in one of four years of evaluation at a depth of 0 to $3 \mathrm{~cm}$ [0 to $1.2 \mathrm{in}$ ], in which soil bulk density was 1.02 and $1.08 \mathrm{Mg} \mathrm{m}^{-3}$ [g $\mathrm{cm}^{-3}$ ] under ungrazed and grazed condition [Franzluebbers and Stuedemann 2008b]). In contrast from the same study, soil penetration resistance to a depth of $30 \mathrm{~cm}$ (12 in) was greater when rye was grazed than ungrazed after the first year, was lower after the second year, and not different after the third year. With pearl millet (Pennisetum glaucum L. R. Br.) as summer crop between wheat grain crops, soil penetration resistance was greater when grazed than when ungrazed in two of six sampling events (Franzluebbers and Stuedemann 2008b). These evaluations suggest that compaction caused by livestock grazing cover crops could be an issue for subsequent crop production, but the

Alan J. Franzluebbers is an ecologist with the USDA Agricultural Research Service (ARS), Raleigh, North Carolina. John A. Stuedemann is a retired animal scientist with the USDA ARS, Watkinsville, Georgia. 
evidence is not overwhelming and may be related to the extent of grazing to achieve a balance between livestock weight gain and sufficient forage mass remaining to protect the soil (Carvalho et al. 2010).

Soil quality is suggested to be assessed from physical, chemical, and biological indices (Doran and Parkin 1994). Soil organic matter and its various fractions are key components of many soil quality indicators, including those indicators defining soil biological quality through soil respiration or C mineralization (Karlen et al. 1997; Haynes and Tregurtha 1999; Carter 2002).

With substantial C input from cover crops, soil microbial biomass and activity can be expected to increase (Buyer et al. 2010; Nair and Ngouajio 2012). The flush of carbon dioxide $\left(\mathrm{CO}_{2}\right)$ following rewetting of dried soil may be a useful tool to rapidly assess soil biological quality, including strong relationships with soil microbial biomass and net nitrogen $(\mathrm{N})$ mineralization (Franzluebbers et al. 2000). Biologically active soil $\mathrm{C}$ and $\mathrm{N}$ fractions might respond positively to grazing of cover crops, as suggested by grazing of perennial pastures as part of an integrated crop-livestock system in Texas (Acosta-Martinez et al. 2010; Davinic et al. 2013). However, few studies have been conducted to know the long-term effects of grazing of cover crops for production and conservation compared with no grazing of cover crops for conservation alone on biologically active soil $\mathrm{C}$ and $\mathrm{N}$ fractions. We observed some early indications that grazing of rye cover crop managed under no tillage (NT) had greater soil microbial biomass C than when ungrazed at a depth of 0 to $6 \mathrm{~cm}$ (0 to 2.4 in; Franzluebbers and Stuedemann 2008a). Potential C mineralization during 24 days was lower with grazing than without grazing of pearl millet under conventional tillage (CT) in this same study.

We hypothesized that grazing of cover crops would enhance active fractions of soil $\mathrm{C}$ and $\mathrm{N}$, because passage of consumed plant materials through the animal rumen and subsequent deposition on the soil as manure could enhance biological activity. An alternative pessimistic hypothesis was that grazing of cover crops would reduce active fractions of soil $\mathrm{C}$ and $\mathrm{N}$ due to reduction in either total plant biomass production or mass loss of $\mathrm{C}$ via digestion in the rumen itself.

\section{Materials and Methods}

Site Characteristics and Management. The experiment was located near Watkinsville, Georgia, United States $\left(33^{\circ} 62^{\prime} \mathrm{N}, 83^{\circ} 25^{\prime}\right.$ $\mathrm{W})$ on Cecil sandy loam and sandy clay loam soils (fine, kaolinitic, thermic Typic Kanhapludults) with $2 \%$ to $6 \%$ slope. Soil was moderately to strongly acidic ( $\mathrm{pH} 5$ to 6). Long-term mean annual temperature was $16.5^{\circ} \mathrm{C}\left(61.7^{\circ} \mathrm{F}\right)$, precipitation was 1,250 $\mathrm{mm}$ (49.3 in), and pan evaporation was $1,560 \mathrm{~mm}$ (61.5 in). Excess precipitation in winter and deficit precipitation in summer are typical for the location.

This investigation builds upon several earlier investigations that described initial field conditions (Franzluebbers and Stuedemann 2008a, 2008b), as well as total soil organic $\mathrm{C}$ and $\mathrm{N}$ dynamics during seven years (Franzluebbers and Stuedemann 2014c). The experimental design from 2002 to 2005 was a factorial arrangement of (1) tillage (CT and NT) and (2) cropping system (summer grain/winter cover crop and winter grain/ summer cover crop) with four replicated paddocks each, for a total of 16 main plots. Main plots were split into grazed (0.5 ha [1.2 ac]) and ungrazed (0.2 ha [0.5 ac]) cover crop treatments.

Tillage systems were: (1) conventional disk tillage (CT) following harvest of each grain and cover crop, and (2) NT with glyphosate to control weeds prior to NT planting. Tillage treatments were initiated in May of 2002. Initial CT treatment consisted of moldboard plowing to a depth of 25 to $30 \mathrm{~cm}(10$ to 12 in). Disk plowing only to a depth of 15 to $20 \mathrm{~cm}$ (6 to 8 in) occurred in subsequent years two to four times between crops, depending on the amount of residue present. Pasture was terminated in the NT treatment with two applications of glyphosate (isopropyl amine salt of $\mathrm{N}$-[phosphonomethyl] glycine, $2.9 \mathrm{~kg}$ active ingredient [a.i.] ha ${ }^{-1}$ [41 $\left.\mathrm{Oz} \mathrm{ac} \mathrm{C}^{-1}\right]$ in May and $1.2 \mathrm{~kg}$ a.i. ha $\mathrm{h}^{-1}[1.1 \mathrm{lb}$ $\mathrm{ac}^{-1}$ ] in June of 2002). Thereafter, glyphosate was applied typically in one pre- or immediately postplanting application (0.8 to $1.7 \mathrm{~kg}$ a.i. ha ${ }^{-1}$ [11 to $24 \mathrm{oz} \mathrm{ac}^{-1}$ ) and sometimes within three weeks after emergence when using glyphosate-tolerant crops.

Cropping systems were intentionally diverse to produce both summer and winter crops each year. Crop rotation changed in 2005, but tillage systems and cover crop management remained consistent during the period of investigation (Franzluebbers and Stuedemann 2014a). The crop rotations were separate sorghum (Sorghum bicolor L. Moench)/rye and wheat/pearl millet systems previously (2002 to 2005) and combined corn (Zea mays L.)/cover crop-wheat/soybean (Glycine max L. Merr.) with no and moderate $\mathrm{N}$ application to ryegrass (Lolium multiflorum Lam.)-crimson clover mix and ryegrass cover crop, respectively (2005 to 2009).

Cover crop management was the following: (1) no grazing and allowing plants to reach early flowering prior to termination, and (2) grazing with cattle to consume $~ 90 \%$ of available forage during 4 to 10 week periods once forage reached $\sim 30 \mathrm{~cm}$ (12 in) tall, irrespective of weather conditions. Cattle stocking rate was managed with a put-andtake approach to equalize available forage among paddocks and treatments within a grazing period. Cover crops were stocked with yearling Angus steers in the first year and Angus cow/calf pairs in other years. Ungrazed cover crops were grown until $\sim 2$ weeks prior to planting of the next crop and either (1) mowed prior to CT operations (disk) as green manure, or (2) mechanically rolled to the ground in the NT system to provide surface mulch.

Application of $\mathrm{N}$ was $74 \pm 58 \mathrm{~kg} \mathrm{~N} \mathrm{ha}{ }^{-1}$ $\mathrm{y}^{-1}\left(66 \pm 52 \mathrm{lb} \mathrm{N} \mathrm{ac}^{-1} \mathrm{yr}^{-1}\right)$ among four different cropping sequences. Crop fertilizer rates and plant and animal production were reported in Franzluebbers and Stuedemann (2007; 2014a), soil-surface responses during early years were reported in Franzluebbers and Stuedemann (2008a, 2008b), and deep-profile soil $\mathrm{C}$ and $\mathrm{N}$ were reported in Franzluebbers and Stuedemann (2014b).

Soil Sampling and Analyses. Soil was collected at the end of $\sim 1$ year of management in February of 2003, at the end of $\sim 3$ years of management in October of 2004 , at the end of $\sim 5$ years of management in February of 2007, and at the end of $\sim 7$ years of management in February of 2009. Although initial soil samples were collected prior to tillage treatment in May of 2002, the results are not presented here to avoid confounding the otherwise strong temporal trends within individual depth increments that were highly dependent upon the subsequent tillage regime. Following collection of surface residue within a $0.04 \mathrm{~m}^{2}\left(0.44 \mathrm{ft}^{2}\right)$ area, a probe $(4 \mathrm{~cm}$ [1.6 in] inside diameter) was used to extract soil to a depth of 30 $\mathrm{cm}$ (12 in), and this was repeated at eight locations in grazed paddocks and at five 
locations in ungrazed paddocks. Cores were sectioned into depth increments of 0 to 3,3 to 6,6 to 12,12 to 20 , and 20 to $30 \mathrm{~cm}(0$ to $1.2,1.2$ to $2.4,3.4$ to $4.7,4.7$ to 8 , and 8 to $12 \mathrm{in}$ ) and the eight or five subsamples pooled. Cattle camping zones near permanent shade and water sources on one side of plots were avoided. Soil samples were dried at $55^{\circ} \mathrm{C}\left(131^{\circ} \mathrm{F}\right)$ for $\geq 3$ days. Bulk density was calculated from the total dry weight of soil and volume of coring device. Soil was passed through a sieve with openings of 4.75 $\mathrm{mm}$ (0.2 in) to homogenize the sample and remove a small fraction $(<1 \%)$ of gravel.

Soil microbial biomass $\mathrm{C}$ was determined with chloroform fumigation-incubation without subtraction of a control and using an efficiency factor of 0.41 (Voroney and Paul 1984; Franzluebbers et al. 1999). The flush of $\mathrm{CO}_{2}$ following rewetting of dried soil ( 3 days) and cumulative $\mathrm{C}$ and $\mathrm{N}$ mineralization during 24 days of incubation were determined with aerobic incubation of soil at $50 \%$ water-filled pore space and $25^{\circ} \mathrm{C}\left(77^{\circ} \mathrm{F}\right)$ (Franzluebbers et al. 1999; Franzluebbers and Stuedemann 2008a). Duplicate soil samples $(27.5 \mathrm{~g}$ [1 oz] in Year 1 and $33 \mathrm{~g}$ [1.2 oz] in Years 3,5 , and 7 for 0 to $3 \mathrm{~cm}$ [0 to 1.2 in] depth; $48 \mathrm{~g}$ [1.7 oz] for 3 to $6 \mathrm{~cm}$ [1.2 to $2.4 \mathrm{in}]$ depth; and $65 \mathrm{~g}[2.3 \mathrm{oz}]$ for 6 to 12 , 12 to 20 , and 20 to $30 \mathrm{~cm} \mathrm{[2.4} \mathrm{to} 4.7,4.7$ to 8 , and 8 to $12 \mathrm{in}$ ] depths) in $60 \mathrm{~mL}(2.1$ oz) glass jars were wetted and placed in a $1 \mathrm{~L}$ (1 qt) canning jar with $10 \mathrm{~mL}(0.4 \mathrm{oz})$ of $\sim 1$ $\mathrm{M}$ sodium hydroxide $(\mathrm{NaOH})$ to trap $\mathrm{CO}_{2}$ and a vial of water to maintain humidity. Alkali traps were replaced at 3 and 10 days of incubation and $\mathrm{CO}_{2}-\mathrm{C}$ determined by titration with $\sim 1 \mathrm{M}$ hydrogen chloride $(\mathrm{HCl})$ in the presence of barium chloride $\left(\mathrm{BaCl}_{2}\right)$ to a phenolphthalein endpoint. At 10 days, one of the subsamples was removed from the incubation jar, fumigated with chloroform $\left(\mathrm{CHCl}_{3}\right)$ under vacuum for one day, vapors removed, placed into a separate canning jar along with vials of alkali and water, and incubated at $25^{\circ} \mathrm{C}\left(77^{\circ} \mathrm{F}\right)$ for 10 days. Potential $\mathrm{C}$ mineralization was calculated from the cumulative evolution of $\mathrm{CO}_{2}$ during 24 days of incubation. Potential $\mathrm{N}$ mineralization was determined from the difference in inorganic $\mathrm{N}$ concentration between 0 and 24 days of incubation. Inorganic $\mathrm{N}\left(\mathrm{NH}_{4}-\mathrm{N}\right.$ $\left.+\mathrm{NO}_{2}-\mathrm{N}+\mathrm{NO}_{3}-\mathrm{N}\right)$ was determined from the filtered extract of a $10 \mathrm{~g}(0.4 \mathrm{oz})$ subsample of dried $\left(55^{\circ} \mathrm{C}\left[131^{\circ} \mathrm{F}\right]\right.$ for 2 days) and sieved $(\leq 2 \mathrm{~mm}[0.1 \mathrm{in}])$ soil that was shaken with $20 \mathrm{~mL}(0.7 \mathrm{oz})$ of $2 \mathrm{M} \mathrm{KCl}$ for 30 minutes using salicylate-nitroprusside and Cd-reduction autoanalyzer techniques (Bundy and Meisinger 1994).

Stratification ratio of biologically active soil $\mathrm{C}$ and $\mathrm{N}$ fractions was calculated as the weighted concentration of a property at 0 to 6 $\mathrm{cm}$ (0 to 2.4 in) depth divided by the concentration at 20 to $30 \mathrm{~cm}$ (8 to 12 in) depth, similar to that proposed by Franzluebbers (2002).

Statistical Analyses. The experimental design was considered a multiple split-block design with 8 replications of 2 tillage $\times 2$ cover crop management regimes. Cover crop management $(n=2)$ was a split plot in horizontal space. Depth of sampling $(n=$ $5)$ was a split plot in vertical space. Year of sampling $(n=4)$ was a split plot in time. The 8 replications were derived from 2 true replications and 4 different cropping sequences (initially screened for differences, but found not to consistently affect responses, and therefore, treated as another source of random variation). Biologically active soil $\mathrm{C}$ and $\mathrm{N}$ fractions within a depth increment were analyzed for variance due to tillage and cover crop management using SAS v. 9.3. Linear regression within a depth was used to test the significance of temporal changes among treatments. Areal estimates of biologically active soil $\mathrm{C}$ and $\mathrm{N}$ fractions were calculated by accounting for differences in bulk density (reported in Franzluebbers and Stuedemann 2014c) and depth. Regressions and correlations among variables were performed with Sigma Plot. Effects were considered significant at $p \leq 0.05$, but trends were noted at $0.05 \leq p \leq 0.10$.

\section{Results and Discussion}

Averaged across years, grazing of cover crops had no significant effect on soil microbial biomass $\mathrm{C}$ (figure 1) or net $\mathrm{N}$ mineralization (figure 2) at any depth, except for a positive effect $(p=0.05)$ on soil microbial biomass C at 3 to $6 \mathrm{~cm}$ (1.2 to $2.4 \mathrm{in})$ under NT (table 1). Therefore, our hypothesis that grazing of cover crops would enhance active fractions of soil $\mathrm{C}$ and $\mathrm{N}$ was supported in only 1 of 10 possible depth increments (i.e., 5 depths $\times 2$ fractions) evaluated.

Soil microbial biomass C was greatest near the soil surface and declined with depth under both CT and NT, but the depth decline was steeper under NT (figure 1). Tillage effects on soil microbial biomass $\mathrm{C}$ were significant at all individual depths- greater concentration under NT than under $\mathrm{CT}$ at 0 to 3 and 3 to $6 \mathrm{~cm}$ (0 to 1.2 and 1.2 to $2.4 \mathrm{in})$ depths and lower concentration under NT than under CT at 6 to 12,12 to 20 , and 20 to $30 \mathrm{~cm} \mathrm{(2.4} \mathrm{to} \mathrm{4.7,} 4.7$ to 8 , and 8 to 12 in) depths. Cumulative to a depth of $30 \mathrm{~cm}$ (12 in), soil microbial biomass $\mathrm{C}$ was not different between tillage systems, either averaged across years $\left(1,601 \mathrm{mg} \mathrm{kg}^{-1}\right.$ [ppm] under both CT and NT) or in Year 7 only. However, the significant tillage $\times$ cover crop management interaction at 0 to $30 \mathrm{~cm}$ depth suggested that grazing inhibited soil microbial biomass $\mathrm{C}$ when crops were managed under CT, but grazing enhanced soil microbial biomass $\mathrm{C}$ when crops were managed under NT. Our hypothesis that grazing of cover crops would enhance soil microbial biomass C was supported, but only under NT and not under CT.

Soil microbial biomass $\mathrm{C}$ was significantly affected by year of sampling at all depths (table 1). At a depth of 0 to $3 \mathrm{~cm}$ (0 to 1.2 in), soil microbial biomass $\mathrm{C}$ declined with time under NT (-66 $\mathrm{mg} \mathrm{kg}^{-1} \mathrm{y}^{-1}\left[\mathrm{ppm} \mathrm{yr}^{-1}\right]$ ), but was relatively stable with time under CT $\left(10 \mathrm{mg} \mathrm{kg}{ }^{-1} \mathrm{y}^{-1}\right)$. At a depth of 3 to $6 \mathrm{~cm}(1.2$ to $2.4 \mathrm{in}$ ), soil microbial biomass $\mathrm{C}$ declined with time under both tillage regimes similarly $\left(-11\right.$ to $\left.-14 \mathrm{mg} \mathrm{kg}^{-1} \mathrm{y}^{-1}\right)$. At a depth of 6 to $12 \mathrm{~cm}$ (2.4 to 4.7 in), soil microbial biomass $\mathrm{C}$ increased with time under both tillage systems similarly (13 to $18 \mathrm{mg} \mathrm{kg}^{-1}$ $\left.\mathrm{y}^{-1}\right)$. At a depth of 12 to $20 \mathrm{~cm}$ (4.7 to 8 in), soil microbial biomass $\mathrm{C}$ declined only slightly with time under $\mathrm{NT}\left(-7 \mathrm{mg} \mathrm{kg}^{-1}\right.$ $\left.\mathrm{y}^{-1}\right)$, while it declined more dramatically with time under CT $\left(-22 \mathrm{mg} \mathrm{kg}^{-1} \mathrm{y}^{-1}\right)$. At a depth of 20 to $30 \mathrm{~cm}$ (8 to 12 in), soil microbial biomass $\mathrm{C}$ declined with time similarly

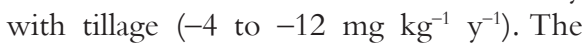
more dramatic decline in soil microbial biomass $\mathrm{C}$ with time under CT at lower depths was likely due to the progressive depletion of soil organic C reserves over time, as indicated also by significant depletions of total and particulate organic $\mathrm{C}$ in this zone (Franzluebbers and Stuedemann 2014c).

Since soil was analyzed for this assessment only after original pasture had been terminated, stratification ratio of soil microbial biomass C was significantly greater under NT than under CT and did not change with time (table 1). Stratification ratio of soil microbial biomass C across years (3.1. versus 6.6 under CT and NT, respectively) was generally of greater absolute value than 


\section{Figure 1}

Mean soil microbial biomass carbon (C) as affected by tillage and cover crop management across sampling events ([a] 1, 3, 5, and 7 years) and regressed upon time as affected by tillage management and soil depth ([b] o to $3 \mathrm{~cm}$, [c] 3 to $6 \mathrm{~cm}$, [d] 6 to $12 \mathrm{~cm}$, [e] 12 to $20 \mathrm{~cm}$, and [f] 20 to $30 \mathrm{~cm}$ ). Error bars in (a) are least significant difference at $p=0.05$ among tillage and cover crop means within a depth and in (b) through (f) are standard deviation for treatments within a year. Note difference in $y$-axis range in $(b)$ through $(f)$.

\section{Soil microbial biomass $\mathrm{C}\left(\mathrm{mg} \mathrm{kg}^{-1}\right)$}

(a)

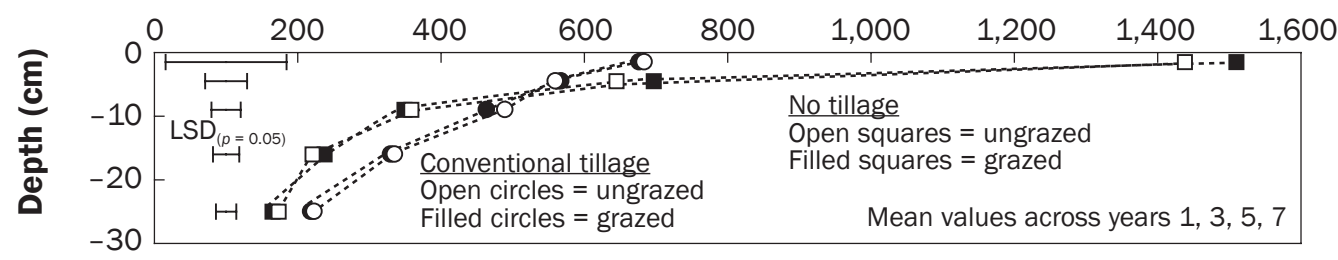

(b)

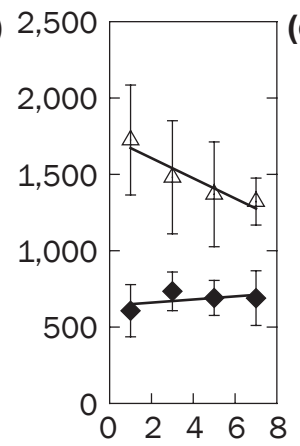

(c)

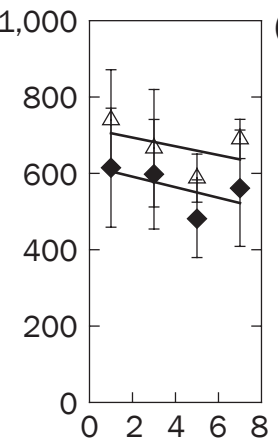

(d)

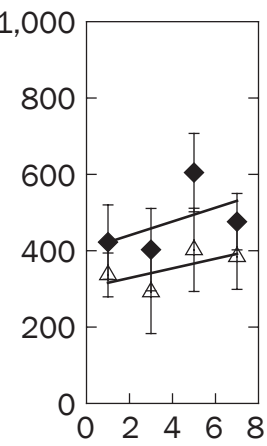

(e)

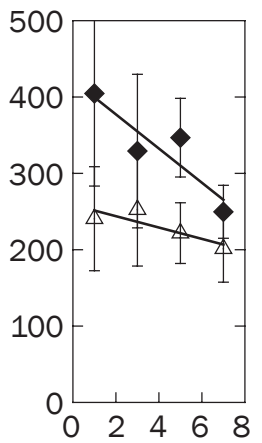

(f)

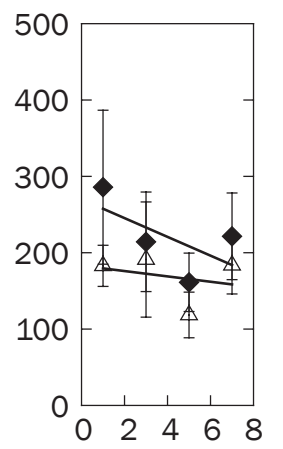

Years of management

stratification ratio of total organic C $(1.9$ versus 5.6 under CT and NT, respectively; Franzluebbers and Stuedemann 2014c), but the relative effect of tillage system on soil response was similar.

The flush of $\mathrm{CO}_{2}$ following rewetting of dried soil was mostly unaffected by whether cover crops were grazed or not (table 1). Only at a depth of 20 to $30 \mathrm{~cm}$ (8 to $12 \mathrm{in}$ ) was there an interaction between tillage and cover crop management, in which the flush of $\mathrm{CO}_{2}$ tended to be greater with grazing than ungrazed management under CT and lower with grazing than ungrazed management under NT. This effect tended to be opposite at a depth of 0 to $6 \mathrm{~cm}$ (0 to 2.4 in), in which grazing improved the flush of $\mathrm{CO}_{2}$ more under NT than under CT. This trend at 0 to $6 \mathrm{~cm}$ ( 0 to 2.4 in) depth was consistent with that of soil microbial biomass $\mathrm{C}$ and partially supported our hypothesis that grazing would enhance biologically active C.

The flush of $\mathrm{CO}_{2}$ increased linearly with time at all depths (table 1). At a depth of 3 to $6 \mathrm{~cm}$ (1.2 to $2.4 \mathrm{in}$ ), the flush of $\mathrm{CO}_{2}$ increased more dramatically with time under NT $\left(22 \mathrm{mg} \mathrm{kg}^{-1} \mathrm{y}^{-1}\right)$ than under CT (13 mg $\left.\mathrm{kg}^{-1} \mathrm{y}^{-1}\right)$. Stratification ratio of the flush of
$\mathrm{CO}_{2}$ was unchanged with time, tending to be greater with grazing than ungrazed management under NT (7.4 versus 7.9 under ungrazed and grazed, respectively) and not different between cover crop management systems under CT (3.1 versus 2.9). The general increase in flush of $\mathrm{CO}_{2}$ with time was likely due to the high $\mathrm{C}$ input from two crops each year (Franzluebbers and Stuedemann 2014c). Greater stratification ratio of the flush of $\mathrm{CO}_{2}$ compared with stratification ratio of soil organic $\mathrm{C}$ has been observed in other studies in Georgia (Franzluebbers et al. 2007), in North Carolina (Franzluebbers and Brock 2007), and in Parana, Brazil (for microbial biomass and basal soil respiration; Sa and Lal 2009), as it reflects greater enrichment of biologically active $\mathrm{C}$ at the soil surface compared with lower depths.

Cumulative C mineralization during 24 days of aerobic incubation responded in a similar manner as soil microbial biomass $\mathrm{C}$ and the flush of $\mathrm{CO}_{2}$ - grazing impacts were mostly nonexistent, except for greater C mineralization with grazing than ungrazed cover crop management under NT and slight depression under CT at a depth of 0 to $6 \mathrm{~cm}$ (0 to 2.4 in; table 1$)$. This grazing interaction at a depth of 0 to $6 \mathrm{~cm}$ was also the reason for a significant interactive effect of tillage $\times$ cover crop management on stratification ratio (0 to $6 \mathrm{~cm} / 20$ to $30 \mathrm{~cm}$ [0 to $2.4 \mathrm{in} / 8$ to $12 \mathrm{in}])$ of cumulative $\mathrm{C}$ mineralization, in which stratification ratio was greater with grazing than ungrazed management under NT and slightly reduced with grazing than ungrazed management under CT.

Cumulative $\mathrm{C}$ mineralization increased with time at all depths, similar to that observed for the flush of $\mathrm{CO}_{2}$ (table 1). In addition, cumulative $\mathrm{C}$ mineralization increased with time more dramatically with NT than with $\mathrm{CT}$ at depths of 3 to $6 \mathrm{~cm}$ (1.2 to $2.4 \mathrm{in}$ ) and 12 to $20 \mathrm{~cm}$ (4.7 to 8 in). A significant tillage $\times$ cover crop management $\times$ time interaction at a depth of 3 to $6 \mathrm{~cm}$ was a result of cumulative $\mathrm{C}$ mineralization increasing at a rate of 12 and $41 \mathrm{mg} \mathrm{kg}^{-1} \mathrm{y}^{-1}\left(\mathrm{ppm} \mathrm{yr}^{-1}\right)$ under CT without and with grazing, while increasing at a rate of 67 and $50 \mathrm{mg} \mathrm{kg}^{-1} \mathrm{y}^{-1}$ under NT without and with grazing, respectively. The other significant three-way interaction occurred for the stratification ratio of cumulative $\mathrm{C}$ mineralization, in which stratification ratio changed with time by -0.1 and $0.3 \mathrm{~g} \mathrm{~g}^{-1}$ $\mathrm{y}^{-1}$ under CT without and with grazing and 
Table 1

Mean soil microbial biomass carbon (C), flush of carbon dioxide $\left(\mathrm{CO}_{2}\right)$ following rewetting of dried soil during 3 days, and cumulative $\mathrm{C}$ mineralization during 24 days averaged across years $(1,3,5$, and 7 years of continuous management) as affected by tillage, cover crop management, and soil depth. Analysis of variance was conducted across years, as well as considering interactions of time with tillage and cover crop management variables.

\begin{tabular}{|c|c|c|c|c|c|c|c|c|c|c|c|}
\hline \multirow[b]{3}{*}{ Soil depth $(\mathrm{cm})$} & \multirow{2}{*}{\multicolumn{2}{|c|}{ Conventional tillage }} & \multirow{2}{*}{\multicolumn{2}{|c|}{ No tillage }} & \multicolumn{7}{|c|}{ Analysis of variance $(\mathrm{Pr}>\mathrm{F})$} \\
\hline & & & & & \multicolumn{3}{|c|}{ Across years } & \multicolumn{4}{|c|}{ Temporal effects } \\
\hline & Ungrazed & Grazed & Ungrazed & Grazed & $\mathbf{T}$ & C & $\mathbf{T} \times \mathbf{C}$ & $\mathbf{Y}$ & $\mathbf{T} \times \mathbf{Y}$ & $\mathbf{C} \times \mathbf{Y}$ & $\mathbf{T} \times \mathbf{C} \times \mathbf{Y}$ \\
\hline \multicolumn{12}{|c|}{ Soil microbial biomass $\mathrm{C}$} \\
\hline \multicolumn{12}{|c|}{$m g \mathrm{~kg}^{-1}$} \\
\hline 0 to 3 & 684 & 677 & 1,438 & 1,510 & $<0.001$ & 0.69 & 0.65 & 0.002 & $<0.001$ & 0.83 & 0.83 \\
\hline 3 to 6 & 560 & 568 & 645 & 697 & 0.03 & 0.12 & 0.05 & 0.02 & 0.82 & 0.41 & 0.15 \\
\hline 6 to 12 & 489 & 464 & 359 & 349 & 0.002 & 0.30 & 0.38 & 0.001 & 0.55 & 0.19 & 0.63 \\
\hline 12 to 20 & 335 & 330 & 221 & 237 & $<0.001$ & 0.77 & 0.77 & $<0.001$ & 0.02 & 0.59 & 0.88 \\
\hline 20 to 30 & 223 & 218 & 173 & 165 & $<0.001$ & 0.32 & 0.87 & 0.006 & 0.12 & 0.54 & 0.95 \\
\hline \multicolumn{12}{|l|}{$\mathrm{kg} \mathrm{ha} \mathrm{a}^{-1}$} \\
\hline 0 to 6 & 459 & 453 & 699 & 767 & $<0.001$ & 0.27 & 0.04 & 0.005 & $<0.001$ & 0.89 & 0.28 \\
\hline 0 to 30 & 1,628 & 1,574 & 1,562 & 1,639 & 0.57 & 0.56 & 0.05 & 0.009 & 0.59 & 0.72 & 0.38 \\
\hline \multicolumn{12}{|l|}{$\mathrm{g} \mathrm{g}^{-1}$} \\
\hline $\begin{array}{l}\text { Ratio of } 0 \text { to } \\
6 \text { to } 20 \text { to } 30\end{array}$ & 3.1 & 3.1 & 6.3 & 7.0 & $<0.001$ & 0.38 & 0.33 & 0.67 & 0.33 & 0.59 & 0.54 \\
\hline \multicolumn{12}{|l|}{ Flush of $\mathrm{CO}_{2}-\mathrm{C}$} \\
\hline \multicolumn{12}{|l|}{$m g k^{-1} 3 d^{-1}$} \\
\hline 0 to 3 & 218 & 227 & 524 & 530 & $<0.001$ & 0.59 & 0.26 & $<0.001$ & 0.79 & 0.71 & 0.15 \\
\hline 3 to 6 & 193 & 193 & 253 & 238 & 0.42 & 0.61 & 0.42 & $<0.001$ & 0.03 & 0.84 & 0.14 \\
\hline 6 to 12 & 150 & 139 & 104 & 105 & $<0.001$ & 0.57 & 0.76 & $<0.001$ & 0.21 & 0.86 & 0.85 \\
\hline 12 to 20 & 112 & 113 & 66 & 64 & $<0.001$ & 0.47 & 0.69 & $<0.001$ & 0.27 & 0.25 & 0.46 \\
\hline 20 to 30 & 74 & 75 & 52 & 50 & 0.002 & 0.45 & 0.03 & $<0.001$ & 0.25 & 0.50 & 0.10 \\
\hline \multicolumn{12}{|l|}{$\mathrm{kg} \mathrm{ha}^{-1} 3 \mathrm{~d}^{-1}$} \\
\hline 0 to 6 & 152 & 154 & 262 & 267 & $<0.001$ & 0.83 & 0.09 & $<0.001$ & 0.37 & 0.58 & 0.07 \\
\hline 0 to 30 & 532 & 523 & 518 & 520 & 0.48 & 0.76 & 0.52 & $<0.001$ & 0.62 & 0.63 & 0.59 \\
\hline \multicolumn{12}{|l|}{$\mathrm{g} \mathrm{g}^{-1}$} \\
\hline $\begin{array}{l}\text { Ratio of } 0 \text { to } \\
6 \text { to } 20 \text { to } 30\end{array}$ & 3.1 & 2.9 & 7.4 & 7.9 & $<0.001$ & 0.38 & 0.06 & 0.43 & 0.28 & 0.40 & 0.06 \\
\hline \multicolumn{12}{|c|}{$\begin{array}{l}\text { Cumulative } \mathrm{C} \text { mineralization } \\
\qquad \mathrm{mg} \mathrm{kg}^{-1} 24 \mathrm{~d}^{-1}\end{array}$} \\
\hline 0 to 3 & 723 & 713 & 1,520 & 1,565 & $<0.001$ & 0.89 & 0.27 & $<0.001$ & 0.92 & 0.98 & 0.39 \\
\hline 3 to 6 & 621 & 614 & 701 & 674 & 0.28 & 0.43 & 0.12 & $<0.001$ & 0.009 & 0.60 & 0.05 \\
\hline 6 to 12 & 481 & 439 & 320 & 301 & $<0.001$ & 0.30 & 0.27 & $<0.001$ & 0.24 & 0.90 & 0.39 \\
\hline 12 to 20 & 316 & 313 & 191 & 190 & $<0.001$ & 0.63 & 0.93 & $<0.001$ & 0.004 & 0.48 & 0.89 \\
\hline 20 to 30 & 189 & 184 & 130 & 127 & $<0.001$ & 0.58 & 0.14 & $<0.001$ & 0.59 & 0.49 & 0.23 \\
\hline \multicolumn{12}{|l|}{$\mathrm{kg} \mathrm{ha}^{-1} 24 \mathrm{~d}^{-1}$} \\
\hline 0 to 6 & 498 & 487 & 747 & 777 & $<0.001$ & 0.52 & 0.03 & $<0.001$ & 0.45 & 0.44 & 0.13 \\
\hline 0 to 30 & 1,586 & 1,520 & 1,475 & 1,486 & 0.01 & 0.73 & 0.15 & $<0.001$ & 0.15 & 0.96 & 0.44 \\
\hline \multicolumn{12}{|l|}{$\mathrm{g} \mathrm{g}^{-1}$} \\
\hline $\begin{array}{l}\text { Ratio of } 0 \text { to } \\
6 \text { to } 20 \text { to } 30\end{array}$ & 3.9 & 3.7 & 8.4 & 8.9 & $<0.001$ & 0.74 & 0.006 & 0.72 & 0.11 & 0.93 & 0.02 \\
\hline
\end{tabular}




\section{Figure 2}

Mean net nitrogen $(\mathrm{N})$ mineralization during 24 days as affected by tillage and cover crop management across sampling events ([a] 1, 3, 5, and 7 years) and regressed upon time as affected by tillage management and soil depth ([b] o to $3 \mathrm{~cm}$, [c] 3 to $6 \mathrm{~cm}$, [d] 6 to $12 \mathrm{~cm}$, [e] 12 to $20 \mathrm{~cm}$, and [f] 20 to $30 \mathrm{~cm}$ ). Error bars in (a) are least significant difference at $p=0.05$ among tillage and cover crop means within a depth and in (b) through (f) are standard deviation for treatments within a year. Note difference in y-axis range in (b) through (f).

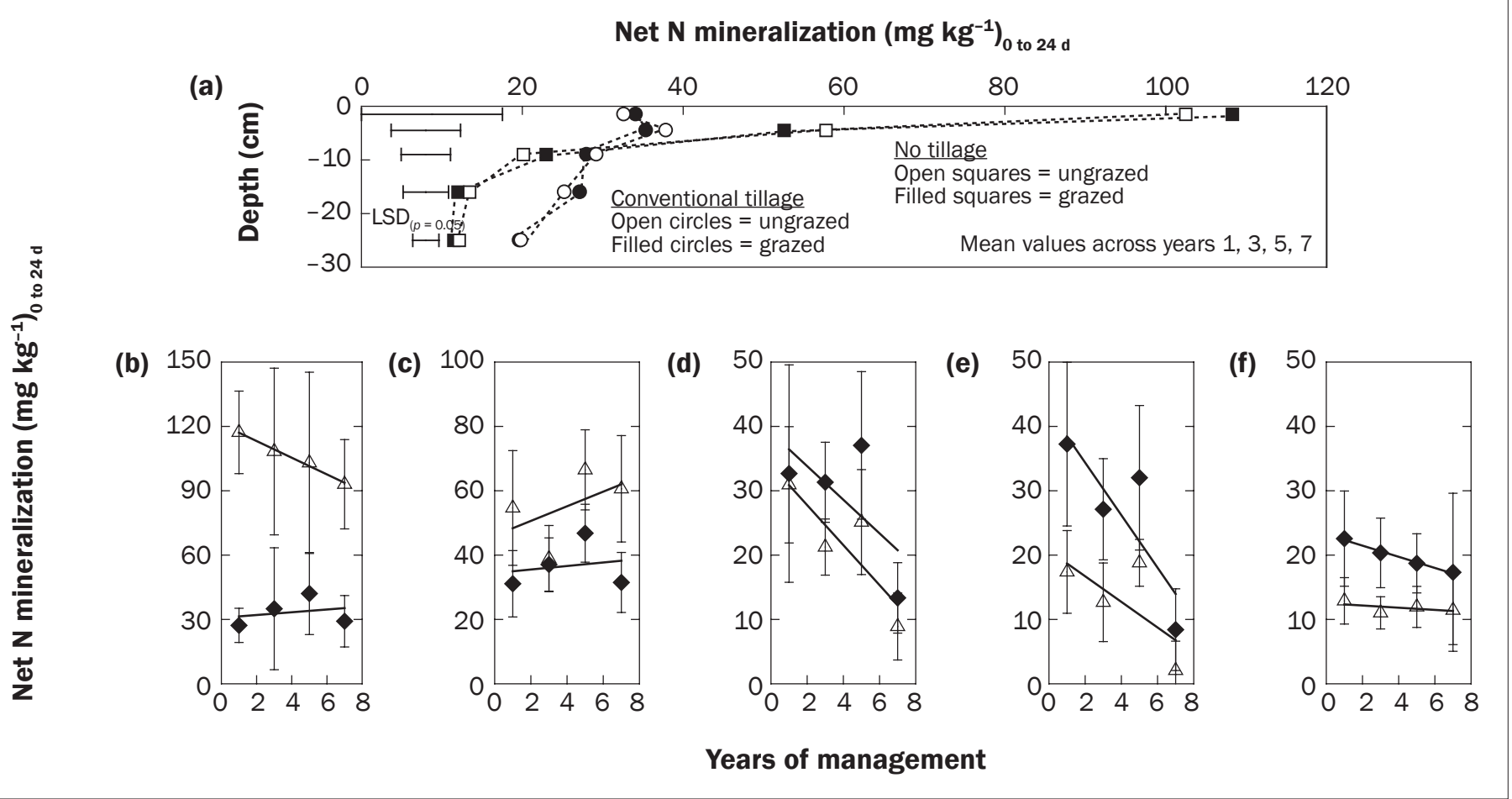

0 and $-0.4 \mathrm{~g} \mathrm{~g}^{-1} \mathrm{y}^{-1}$ under NT without and with grazing, respectively.

As a proportion of total organic C (TOC), cumulative $\mathrm{C}$ mineralization during 24 days of incubation was little affected by cover crop management except at a depth of 3 to $6 \mathrm{~cm}$ (1.2 to $2.4 \mathrm{in}$; table 2). The proportion was reduced with grazing compared with ungrazed cover crop management (average of 40 and $38 \mathrm{mg} \mathrm{CO}-\mathrm{C} \mathrm{g}^{-1}$ TOC [24 $\mathrm{d}^{-1}$ ] under ungrazed and grazed conditions, respectively). Contrary to cumulative C mineralization per mass of soil, the proportion of TOC as $\mathrm{C}$ mineralization was greater under CT than under NT at all depths, except at 20 to $30 \mathrm{~cm}$ (8 to 12 in) where there was no difference. This ratio indicates that the proportion of TOC as biologically active $\mathrm{C}$ was greater under $\mathrm{CT}$ than under NT, suggesting that high crop residue input in this double cropping system was contributing significantly to biological soil quality under both CT and NT. Previous literature studies on high intensity cropping systems also indicate that the proportion of TOC as $\mathrm{C}$ mineralization can be greater under CT than under NT, whereas under low intensity cropping systems the proportion is more likely lower under CT than under NT (Franzluebbers et al. 1994).

The proportion of TOC as cumulative C mineralization during 24 days did increase more over time with NT than under CT at soil depths other than the very surface (table $2)$. The change in the proportion with time was -1.1 and $1.0 \mathrm{mg} \mathrm{CO}_{2}-\mathrm{C} \mathrm{g}^{-1}$ TOC (24 d) $)^{-1} \mathrm{y}^{-1}\left(\mathrm{ppm} 24 \mathrm{~d}^{-1} \mathrm{yr}^{-1}\right)$ at a depth of 3 to 6 $\mathrm{cm}$ (1.2 to $2.4 \mathrm{in})$ under CT and NT, respectively; 0.1 and $1.6 \mathrm{mg} \mathrm{CO}-\mathrm{C} \mathrm{g}^{-1}$ TOC (24 d) $)^{-1} \mathrm{y}^{-1}$ at a depth of 6 to $12 \mathrm{~cm}$ (2.4 to 4.7 in); and 0.9 and $2.0 \mathrm{mg} \mathrm{CO}_{2}-\mathrm{C} \mathrm{g}^{-1}$ TOC $(24 \mathrm{~d})^{-1} \mathrm{y}^{-1}$ at a depth of 12 to $20 \mathrm{~cm}$ (4.7 to 8 in). This interaction between tillage and time interacted further with depth, such that balancing effects at 0 to 3 and 20 to $30 \mathrm{~cm}(0$ to 1.2 and 8 to 12 in) depths resulted in no interaction between tillage and time when summed to a depth of 0 to $30 \mathrm{~cm}$.

Net $\mathrm{N}$ mineralization during 24 days of aerobic incubation was completely unaffected whether cover crops were grazed or left ungrazed at all soil depths (figure 2; table 2). This was a surprising result based on our hypothesis that ingestion of C-rich cover crops by grazing animals would lead to a loss of $\mathrm{C}$ and a concentration of $\mathrm{N}$ that could contribute to a growing fraction of biologically active N. Deposition of assumed higher $\mathrm{C}: \mathrm{N}$ cover-crop residues compared with lower $\mathrm{C}: \mathrm{N}$ animal manure on the soil surface appeared to be equally effective in controlling net $\mathrm{N}$ mineralization at the soil surface and below. Our alternative hypothesis that net $\mathrm{N}$ mineralization might be negatively affected by grazing due to limitation on $\mathrm{N}$ uptake in cover crops was also not supported.

Depth distribution of net $\mathrm{N}$ mineralization was greatly affected by tillage regime (figure 2; table 2). Like that of biologically active soil $\mathrm{C}$ fractions, net $\mathrm{N}$ mineralization was enriched under NT compared with CT at the soil surface and depleted under NT compared with CT below $12 \mathrm{~cm}$ (4.7 in) depth. At a depth of 0 to $3 \mathrm{~cm}$ (0 to $1.2 \mathrm{in}$ ) under NT, net $\mathrm{N}$ mineralization was nearly three times that under CT. This effect diminished greatly at a depth of 3 to $6 \mathrm{~cm}$ (1.2 to 2.4 in), and no difference occurred between tillage systems at a depth of 6 to $12 \mathrm{~cm}(2.4$ to $4.7 \mathrm{in}$ ). Below $12 \mathrm{~cm}$ (4.7 in), net $\mathrm{N}$ mineralization under NT was about half that under CT.

Cumulatively to a depth of $30 \mathrm{~cm}$ (12 in) depth, net $\mathrm{N}$ mineralization was not differ- 
Table 2

Mean net $\mathrm{N}$ mineralization during 24 days of aerobic incubation, residual soil inorganic nitrogen $(\mathrm{N})$, and proportion of total organic carbon (C) as cumulative $C$ mineralization during 24 days averaged across years $(1,3,5$, and 7 years of continuous management) as affected by tillage, cover crop management, and soil depth. Analysis of variance was conducted across years, as well as considering interactions of time with tillage and cover crop management variables.

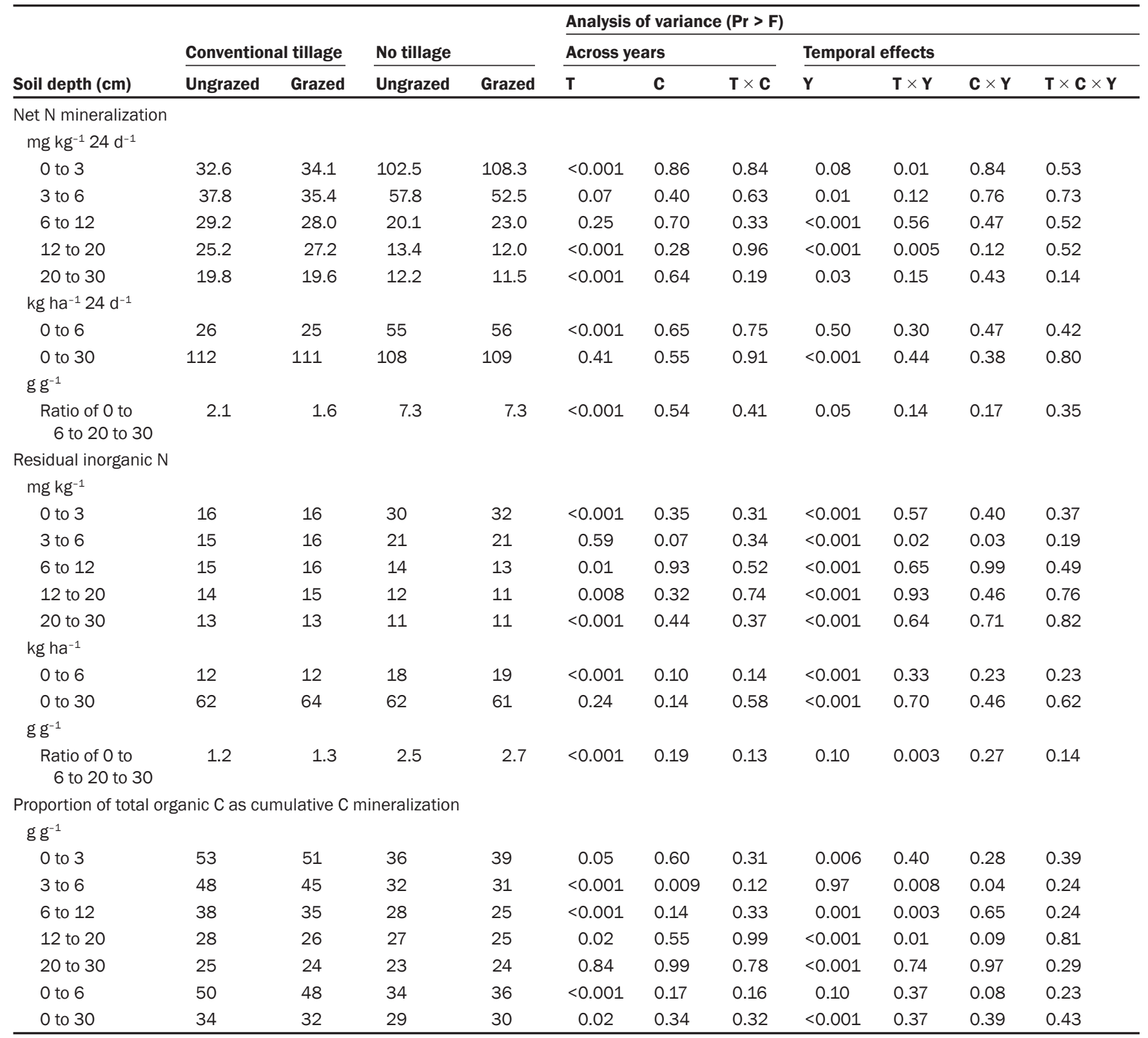

Notes: $T$ is tillage (conventional and no tillage), $C$ is cover crop (ungrazed and grazed), and $Y$ is year (1, 3, 5, and 7 years; linear effect analyzed). Analysis of variance across years had 21 degrees of freedom in error term and to determine temporal effects had 92 degrees of freedom in error term.

ent between tillage systems (either across years or solely in Year 7) and the only significant effect at this cumulative depth was for a general decline of $6.4 \mathrm{~kg} \mathrm{ha}^{-1} \mathrm{y}^{-1}\left(5.7 \mathrm{lb} \mathrm{ac}^{-1}\right.$ $\left.\mathrm{yr}^{-1}\right)$. At a depth of 0 to $3 \mathrm{~cm}$ (0 to $\left.1.2 \mathrm{in}\right)$, change in net $\mathrm{N}$ mineralization according to tillage regime was 0.6 and $-3.9 \mathrm{mg} \mathrm{kg}^{-1} \mathrm{y}^{-1}$ (ppm $\mathrm{yr}^{-1}$ ) under CT and NT, respectively. At a depth of 12 to $20 \mathrm{~cm}$ (4.7 to $8 \mathrm{in}$ ), the dynamic was -4.1 and $-2.0 \mathrm{mg} \mathrm{kg}^{-1} \mathrm{y}^{-1}$ under CT and NT, respectively. Tillage regime did not alter the dynamics of net $\mathrm{N}$ mineralization at other depth increments.

Residual soil inorganic $N$ was not affected by cover crop management, except for an interaction with time, in which inorganic $\mathrm{N}$ increased more dramatically with time when cover crops were ungrazed (3.4 mg $\left.\mathrm{kg}^{-1} \mathrm{y}^{-1}\left[\mathrm{ppm} \mathrm{yr}{ }^{-1}\right]\right)$ than when grazed (2.3 $\left.\mathrm{mg} \mathrm{kg}^{-1} \mathrm{y}^{-1}\right)$. Residual inorganic $\mathrm{N}$ was generally affected in a similar manner to that of net $\mathrm{N}$ mineralization (table 2), reflecting a portion of the $\mathrm{N}$ mineralization potential that occurred in situ, despite crop $\mathrm{N}$ uptake, leaching, volatile losses, and $\mathrm{N}$ fertilizer additions that would have altered inorganic $\mathrm{N}$ availability in the field as compared to 
controlled incubation conditions in the lab. Stratification of residual inorganic N occurred under NT and was largely absent under CT. A general increase in residual inorganic $\mathrm{N}$ occurred with time at all depths, equivalent to $\sim 3 \mathrm{mg} \mathrm{kg}^{-1} \mathrm{y}^{-1}$ at depths of 0 to 3 and 3 to $6 \mathrm{~cm}$ (0 to 1.2 and 1.2 to 2.4 in) and $\sim 2 \mathrm{mg} \mathrm{kg}^{-1} \mathrm{y}^{-1}$ at depths of 6 to 12,12 to 20 , and 20 to $30 \mathrm{~cm} \mathrm{(2.4} \mathrm{to} 4.7,4.7$ to 8 , and 8 to 12 in). Stratification ratio of residual soil inorganic $\mathrm{N}$ changed differently with time by tillage regime from stable under $\mathrm{CT}$ to $-0.1 \mathrm{~g} \mathrm{~g}^{-1} \mathrm{y}^{-1}$ under NT.

\section{Summary and Conclusions}

Overall, grazing of cover crops enhanced biologically active $\mathrm{C}$ fractions, mostly under NT and mostly near the soil surface, but did not affect net $\mathrm{N}$ mineralization or residual soil inorganic $\mathrm{N}$. No-tillage management of these high-intensity cropping systems following termination of perennial pasture preserved the stratified distribution of biologically active soil $\mathrm{C}$ and $\mathrm{N}$ fractions. With high $\mathrm{C}$ input from two crops per year, biologically active $\mathrm{C}$ and $\mathrm{N}$ fractions mostly increased with time under both CT and NT, although a significant decline in soil microbial biomass $\mathrm{C}$ and net $\mathrm{N}$ mineralization occurred under CT at 12 to $20 \mathrm{~cm}$ (4.7 to 8 in) depth. These results suggest that grazing of cover crops did not have negative effects on biologically active $\mathrm{C}$ and $\mathrm{N}$ fractions, but grazing also had minimal positive impact. Results also indicate that NT cropping was the most effective at preserving biologically active soil $\mathrm{C}$ and $\mathrm{N}$ fractions following pasture termination, although cropping with robust cover crops was able to feed the soil sufficiently even with CT that biologically active $\mathrm{C}$ and $\mathrm{N}$ fractions were many times not different from those under NT, when considering the 0 to $30 \mathrm{~cm}$ (0 to 12 in) depth. Grazing of cover crops in the southeastern United States can be recommended, and due to the economic benefit from cattle gain rather than simple cost of planting a cover crop, it is conceivable that the strategy of cover crop grazing could help promote greater adoption of cover crop utilization on more farms throughout the region.

\section{Acknowledgements}

Thanks go to Steven Knapp (biological science technician, USDA Agricultural Research Service [ARS], Athens, Georgia) for excellent management of field and laboratory work on this project. We also thank Dwight Seman (sup- port scientist, USDA ARS, Lexington, Kentucky) and C.J. O'Mara (agricultural specialist, University of Georgia, Watkinsville, Georgia) for managing cattle and Carson Pruitt, Zack Schroer, Kelley and Kim Lyness, Josh Cown, Amanda Limbaugh, Faye Black, Stephanie Steed, and Devin Berry (all former student biological science aids) for their assistance while students. Additional thanks to Ellen Leonard (research technician, North Carolina State University, Raleigh, North Carolina) for completing the analyses of extractable N. Early financial support was provided by USDA National Research Initiative Competitive Grants Program (Agr. No. 2001-35107-11126) and the Georgia Agricultural Commodity Commission for Corn. This study was also supported by USDA ARS base funding, and contributed to the GRACEnet project.

\section{References}

Acosta-Martínez, V., C.W. Bell, B.E.L. Morris, J. Zak, and V.G. Allen. 2010. Long-term soil microbial community and enzyme activity responses to an integrated croppinglivestock system in a semi-arid region. Agriculture, Ecosystems and Environment 137:231-240.

Buyer, J.S., J.R. Teasdale, D.P. Roberts, I.A. Zasada, and J.E. Maul. 2010. Factors affecting soil microbial community structure in tomato cropping systems. Soil Biology and Biochemistry 42:831-841.

Bundy, L.G., and J.J. Meisinger. Nitrogen availability indices. In Methods of Soil Analysis, Part 2, eds. Weaver, R.W., J.S. Angle, and P.S. Bottomley, 951-984. Madison, WI: Soil Science Society of America Book Series 5.

Carter, M.R. 2002. Soil quality for sustainable land management: Organic matter and aggregation interactions that maintain soil functions. Agronomy Journal 94:38-47.

Carvalho, P.C.F., I. Anghinoni, A. Moraes, E.D. Souza, R.M. Sulc, C.R. Lang, J.P.C. Flores, M.L.T. Lopes, J.L.S. Silva, O. Conte, C.L. Wesp, R. Levien, R.S. Fontaneli, and C. Bayer. 2010. Managing grazing animals to achieve nutrient cycling and soil improvement in no-till integrated systems. Nutrient Cycling in Agroecosystems 88:259-273.

Davinic, M., J. Moore-Kucera, V. Acosta-Martínez, J. Zak, and V. Allen. 2013. Soil fungal distribution and functionality as affected by grazing and vegetation components of integrated crop-livestock agroecosystems. Applied Soil Ecology 66:61-70.

Delgado, J.A., P.M. Groffman, M.A. Nearing, T. Goddard, D. Reicosky, R. Lal, N.R. Kitchen, C.W. Rice, D. Towery, and P. Salon. 2011. Conservation practices to mitigate and adapt to climate change. Journal of Soil and Water Conservation 66(4):118A-129A, doi:10.2489/ jswc.66.4.118A.

Doran, J.W., and T.B. Parkin. 1994. Defining and assessing soil quality. In Defining Soil Quality for a Sustainable Environment, 3-21. Madison, WI: Soil Science Society of America Special Publication Number 35.
Franzluebbers, A.J. 2002. Soil organic matter stratification ratio as an indicator of soil quality. Soil and Tillage Research 66:95-106.

Franzluebbers, A.J. 2010. Achieving soil organic carbon sequestration with conservation agricultural systems in the southeastern United States. Soil Science Society of America Journal 74:347-357.

Franzluebbers, A.J., and B.G. Brock. 2007. Surface soil responses to silage cropping intensity on a Typic Kanhapludult in the piedmont of North Carolina. Soil and Tillage Research 93:126-137.

Franzluebbers, A.J., R.L. Haney, and F.M. Hons. 1999. Relationships of chloroform fumigation-incubation to soil organic matter pools. Soil Biology and Biochemistry 31:395-405.

Franzluebbers, A.J., F.M. Hons, and D.A. Zuberer. 1994. Long-term changes in soil carbon and nitrogen pools in wheat management systems. Soil Science Society of America Journal 58:1639-1645.

Franzluebbers, A.J., H.H. Schomberg, and D.M. Endale. 2007. Surface-soil responses to paraplowing of longterm no-tillage cropland in the Southern Piedmont USA. Soil and Tillage Research 96:303-3015.

Franzluebbers, A.J., and J.A. Stuedemann. 2007. Crop and cattle responses to tillage systems for integrated croplivestock production in the Southern Piedmont, USA. Renewable Agriculture and Food Systems 22:168-180.

Franzluebbers, A.J., and J.A. Stuedemann. 2008a. Early response of soil organic fractions to tillage and integrated crop-livestock production. Soil Science Society of America Journal 72:613-625.

Franzluebbers, A.J., and J.A. Stuedemann. 2008b. Soil physical responses to cattle grazing cover crops under conventional and no tillage in the Southern Piedmont USA. Soil and Tillage Research 100:141-153.

Franzluebbers, A.J., and J.A. Stuedemann. 2014a. Crop and cattle production responses to tillage and cover-crop management in an integrated crop-livestock system in the southeastern USA. European Journal of Agronomy 57:62-70.

Franzluebbers, A.J., and J.A. Stuedemann. 2014b. Soilprofile distribution of organic $\mathrm{C}$ and $\mathrm{N}$ after 6 years of tillage and grazing management. European Journal of Soil Science 64:558-566.

Franzluebbers, A.J., and J.A. Stuedemann. 2014c. Temporal dynamics of total and particulate organic carbon and nitrogen in cover crop grazed cropping systems. Soil Science Society of America Journal 78:1404-1413.

Haynes, R.J., and R. Tregurtha. 1999. Effects of increasing periods under intensive arable vegetable production on biological, chemical and physical indices of soil quality. Biology and Fertility of Soils 28:259-266.

Hinsinger, P., A.G. Bengough, D. Vetterlein, and I.M. Young. 2009. Rhizosphere: Biophysics, biogeochemistry and ecological relevance. Plant and Soil 321:117-152.

Karlen, D.L., M.J. Mausbach, J.W. Doran, R.G. Cline, R.F. Harris, and G.E. Schuman. 1997. Soil quality: A 
concept, definition, and framework for evaluation. Soil Science Society of America Journal 61:4-10.

Mullins, G.L., and C.H. Burmester. 1997. Starter fertilizer and the method and rate of potassium fertilizer effects on cotton grown on soils with and without winter grazing by cattle. Communications in Soil Science and Plant Analysis 28:739-746.

Nair, A., and M. Ngouajio. 2012. Soil microbial biomass, functional microbial diversity, and nematode community structure as affected by cover crops and compost in an organic vegetable production system. Applied Soil Ecology 58:45-55.

Sa, J.C.M., and R. Lal. 2009. Stratification ratio of soil organic matter pools as an indicator of carbon sequestration in a tillage chronosequence on a Brazilian Oxisol. Soil and Tillage Research 103:46-56.

Sainju, U.M., W.F. Whitehead, and B.P. Singh. 2005. Biculture legume-cereal cover crops for enhanced biomass yield and carbon and nitrogen. Agronomy Journal 97:1403-1412.

Schomberg, H.H., D.S. Fisher, D.W. Reeves, D.M. Endale, R.L. Raper, K.S.U. Jayaratne, G.R. Gamble, and M.B. Jenkins. 2014. Grazing winter rye cover crop in a cotton no-till system: Yield and economics. Agronomy Journal 106:1041-1050.

Schomberg, H.H., R.G. McDaniel, E. Mallard, D.M. Endale, D.S. Fisher, and M.L. Cabrera. 2006. Conservation tillage and cover crop influences on cotton production on a southeastern U.S. Coastal Plain soil. Agronomy Journal 98:1247-1256.

Voroney, R.P., and E.A. Paul. 1984. Determination of $\mathrm{kC}$ and $\mathrm{kN}$ in situ for calibration of the chloroform fumigation-incubation method. Soil Biology and Biochemistry 16:9-14. 